\title{
Promote the higher education connotation development research
}

\author{
Shuoyi $\mathrm{He}^{1}$ \\ ${ }^{1}$ Tianjin university of finance and economics, China
}

Keywords: Higher Education; University Governance; The Connotative Development.

\begin{abstract}
After leaping development of higher education in our country, university education scale, the level of subject construction has the larger, higher education reform and development has entered the connotative development new stage. With the expanding of university decision-making right, the colleges and universities of changes have taken place in the decision-making system and management system, how to optimize configuration, straightening out relations, to further enhance the level of university education in our country and become a hot topic of higher education reform. In Chinese universities are facing by relying on the administrative power of running a school, gradually converted to follow the inherent logic and law of colleges and universities, true education, democratic supervision, in accordance with the social participation of university governance structure.
\end{abstract}

\section{Introduction}

The national medium and long-term education reform and development plan outline (2010-2020) of higher education reform and development problems, and put forward to further reform and improve the management of the government, guarantee of university autonomy, also highlighted the university needs to further perfect the governance structure, deepening reform of management system, pay attention to the connotation development of higher education reform.

\section{The Status And Problems Of University Governance Structure In Our Country}

University governance structure is not a simple abstract theory, it is the product of the era development and the deepening of the research. University governance structure is the basic system of running school, the core is "right" and "interest" as the core. The focus of university governance structure is the reasonable configuration and operation of power, through the reasonable allocation of multiple power, realize the coordination of the university of run efficiently, realizing the lawful and reasonable administration of the school.

University governance structure is mainly divided into two most, external governance and internal governance. External governance structure are mostly about the university and the market, and the interdependence of the whole system of society, a symbiotic relationship, problems of external governance structure embodies a concentrated reflection of right distribution between university and government aspects. Internal governance structure is mainly related to the horizontal and vertical relationship of the university internal governance and the allocation of rights, in particular are mostly about the problems between the core stakeholders, such as the communist party leadership, the principal executive power, professor research academic power, the democratic supervision and so on.

Present Situation And Problems Of The University Of External Governance Structure In Our Country. From the perspective of the external governance structure of universities, the government's executive power and the autonomy of higher conflict and imbalance is an important problem in the development of higher education. At present, our country university host is the government, university education is the government planning is given priority to, on the management of our university is mainly rely on administrative commands issued by the government, through administrative means. Since China's reform and opening up, although university to obtain a degree of school-running autonomy, but from the point of the present situation, the relationship between the government and university, in fact is a kind of control and controlled dependence, adopt the management mode of our country university is in accordance with the policy of managing the government administrative pattern in colleges and universities. 
The Present Situation And Problems Of The Governance Structure In Colleges And Universities Of Our Country. At present, the university internal management system is "the President responsibility system under the leadership of the communist party", the management system, after many years of practice and summary to the higher education law of the People's Republic of China of the system was established. In the process of the development of university in China, however, because the administrative power is too large and cause some of the problems are also starting to show. For example: academic power weakening, the phenomenon of academic security administration; Is the party and government too much power, has a "big administrative, small academic" problem; Is the responsibility of party and government power boundary is not enough clear, inadequate teachers and students to participate in the governance of democratic problems, such as this to a certain extent, affected the overall efficiency of higher institution and to follow the universities own development laws.

And the most attention in the governance structure in colleges and universities of our country and the most outstanding contradiction conflict is the executive power and academic power. Characteristic of the university is different from other social organization is the existence of administrative power and academic power coexist dual structure. Academic power is academic activity itself, from the scientific knowledge and truth to explore the internal logic of the decision, no strict rules based on the academic power. While the administrative power is given by the university of system, is by the administrative personnel through the legal rights of administrative management, has the obvious characteristics of different levels. From the point of university development demand in China, teachers with academic power and administrative power, administrative management, university of common governance, jointly decided the development direction of the university, the allocation of resources and other major decision making problems, is in accordance with the basic system arrangement of the law of development of higher education in our country.

\section{The System Construct Of University Governance Structure And Mode}

University is integrating teaching, scientific research and social service function of complex academic social organizations, the development of the university should fully respect the freedom of academic development, also should have strong party and government management. Perfect governance structure, university should not only pay attention to the establishment of university governance concept, pay attention to the top-level design, also want to establish a core stakeholders co-governance mode.

The Principle Of Building University Governance System. System construct of university governance structure should fully respect the university educational law, following the organizational characteristics of university construction. University of both academic and hierarchical characteristics, should not only respect the elite school, the teacher should play the role of academic authority, and to adhere to the clear direction of running a school and party leaders. Activity is the essence of university academic activities, should follow the inherent law of academic development, promote the connotation development of higher education, at the same time, the university is closely connected with the social economic and cultural development of our country, university to cultivate talents for the society of the social service function, therefore also want to handle the relationship between the university and society, formed the benign interaction.

The Main Part Of University Governance Structure System Builds. System construct of university governance structure mainly includes two parts: the part is at the top of system design, including the goal of university governance structure and governance rights between structure and power restriction mechanism, etc. On the basis of top-level design and hierarchical design, top-down advance step by step. The other part is the design of university internal management system, including system establishment, update and improve, through the concrete system design realize the rational allocation and effective running of the management, management standardization, standardization.

The Pattern Of Our Country's University Governance Structure. Group think at present, is suitable for effective university governance structure should be adhering to the core concept of 
stakeholder governance of university governance model, the core stakeholders governance at the university of the legitimate rights and interests of stakeholders, not only ensure the university also avoids decision-making caused by scattered control problems such as inefficient, core stakeholders co-governance university is the realistic demand of effective governance model, is advantageous to the university of our country a better play to the talent training, scientific research, service society's positive role.

\section{Improve University Governance Structure, And Promote The Higher Education Connotation Development Strategy Analysis}

To improve university governance structure, not only to build the perfect governance mechanism and mode, more thoroughly change the university core stakeholders behavior. At the same time, to clarify the responsibilities of various rights boundary, coordinate various relations, set up political, administrative, academic, democratic rights and other rights between the checks and balances mechanism, realize reasonable allocation of rights to use.

Shift The Core Stakeholders Behavior, Improve The Governance Structure. Clarify the boundaries between government and university, realize the government management limited. Since the reform and opening, the relationship between government and universities happened some change, got a certain degree of autonomy of running a school at the university. Although the government is trying to establish both can realize the government management function and can promote university development pattern, but in fact the present university or the government-led governance mode. As university of public schools, the government provides the main school funding for the school above reproach, but in other ways need to change the excessive management pattern, reduce interference, university of reduce reliance on the government. Such as: to establish a more reasonable resource allocation, change the traditional top-down to inherent in the project of 985, 211 engineering as a standard form of colleges and universities the allocation of resources, create a more fair opportunity for all universities. To build a more fair and standardization of university evaluation, evaluation plan, evaluation project and the form is more reasonable, assessment results will not affect the interests and the allocation of resources and so on.

Reduce the teachers' academic security administration tendency, play the role of academic management. Teacher is the representative of the academic power in university governance, by can foster "learning" and so on the influence of traditional concepts, at present our country university, a good teacher must be given in terms of academic performance of administrative posts has become a convention, schools of various resources will often tend to give priority to configure for teachers with administrative duties, which leads to the tendency of teachers' academic town government. University to achieve better respect is the key of the development of the inherent law of academic activities, maintaining academic freedom and prosperity. Therefore, for academic affairs should be handed over to the teacher in the university academic organizations for final decision, will return to academic departments, academic issues through the establishment of the academic committee, discipline evaluation committee and other academic institutions, teachers, clarify its functions and rights, and ensure that the motion of the academic power, safeguard the teachers of academic resources configuration and right of use.

Establish encouraging students to actively participate in university governance platform. Change students passively accept school management consciousness, arouse the enthusiasm of students, and establish the students actively participate in school management, the exercise of power, the opinion of the platform. Change students just the idea of educatees, establish the student is able to play an ego education in university management, and actively participate in university governance subject consciousness, by conducting a student symposium, with the help of a campus network, the student union, the principal mailbox, good for the students involved in school management to build channels and platforms.

Play a role of alumni actively, and common development for the university. Alumni as once lived in Alma mater learning group, the Alma mater has a natural connection and attention, alumni inner will want to actively participate in school management, set up mutual trust between universities and 
alumni, long-term relations of cooperation, the school should fully arouse the enthusiasm of alumni actively participate in university governance activities, through the establishment of alumni association and other communications agencies, to create good conditions and environment for alumni to participate in university governance.

Improve Management Mechanism, Promote The Development Of Higher Education Connotation. We will adhere to and improve the President responsibility system under the leadership of the party committee. "The President responsibility system under the leadership of party committees" is our country's higher education after long term exploration experiences, both embodies the leadership of party committee and reflects the principal of the administrative power. Right to play on the one hand, the direction of the party committee politics grasp, grasp the school-running orientation of university, to maintain the stability of running school. Play, on the other hand, the principal of the administrative enforcement, such as the development of the discipline of the school, the teaching manage administrative affairs, to accept the leadership of the party and supervision.

Establish and improve the mechanism of the professor scholarship. Academic attributes is the basic attribute of university, and maintain the vitality of the academic is the source of university development. In order to realize the efficient operation of university governance, maintain the advanced nature of the academic, need to deal with the relationship between the administrative power and academic power, fully respect the academic authority, establish and improve the mechanism of the professor scholarship, play to the role of the academic institutions, the school management by academic institutions, academic issues.

To speed up the articles of association of the university management system formulated and revised. The articles of association of the university is in accordance with the management at the university of the constitution, is the tenet, institutions and other major at the university of basic problems to conduct a comprehensive interpretation of the specification, the articles of association of the university helps to fundamentally solve the problem of the system construction of scientific and democratic education. Our country university should develop as soon as possible in accordance with the university development orientation and characteristics of the articles of association of the university, and combining with the actual development needs, the university internal management system to conduct a comprehensive revision and improvement of realize scientific management, administration according to law.

Promote the democratic management and supervision. To improve university governance structure, to give full play to teachers and students of democratic management and supervision of power, the teachers and students of school affairs' right to know, to participate, supervise. On the one hand, adhere to the implementation of party affairs, government affairs public, the school stakeholders' right to know. Fully listen to the teacher, on the other hand, the students' opinions and Suggestions, arouse the enthusiasm of teachers and students, and expand the participation way, active play to the role of the students and teach a workers congress congress, let the teachers and students actively participate in university governance, ensure that the teachers and students' democratic rights, safeguard its supervision of school affairs.

Improve university governance structure is to reform and perfect the management system and mechanism, through to the university political, administrative, the establishment of academic power operation mechanism, further defined boundary power, realization of the effective operation of power, at the same time set up the checks and balances of power, build and adapt to the social development, the development of higher education in our country law of university governance structure, promote the development of higher education connotation.

\section{References}

[1] Weian li, shi-quan wang. University governance. Mechanical industry publishing house. 2013 (9).

[2] The national medium and long-term education reform and development plan outline (2010-2020) . 
[3] Yi-zu gong. University governance structure: the cornerstone of modern university system [J]. Journal of education research, 2009 (6) .

[4] Hai-sheng pan, zhangyu. Stakeholders and the construction of a modern university governance structure [J]. Journal of education review, 2007 (1) .

[5] Fang wan.Go to the town of jurisprudence thinking about colleges and universities. Journal of tianjin teach science college, 2011 (8). 